\title{
Student Perspectives on Learning Experiences in a Higher Education Active Blended Learning Context
}

\author{
Alejandro Armellini ${ }^{1} \cdot$ Virgínia Teixeira Antunes $^{2} \cdot$ Robert Howe $^{3}$ (D) \\ Accepted: 8 February 2021 / Published online: 26 February 2021 \\ (C) The Author(s) 2021
}

\begin{abstract}
This article focuses on university students' perceptions of their learning and social experiences in the context of an institutionwide pedagogic shift to Active Blended Learning (ABL). It explores students' perceived enablers and barriers to learning in the new environment. Thematic analysis was conducted on data collected through focus groups involving 60 students. Three key categories emerged: (1) learning experiences, (2) social experiences and (3) support provision. Findings suggest that quality learning experiences are necessary but not sufficient to provide a quality overall student experience. Tutors play a key role in both. Staff-student partnerships are central to promote learner engagement and a sense of belonging. Students value, above all, regular synchronous and asynchronous interaction with peers, tutors and content, enabled by sound pedagogic design and the appropriate deployment of digital technologies. Employability-focused activities that explicitly link theory and practice are regarded as an essential ingredient in learning and assessment. Students view support as a holistic term that integrates academic and pastoral aspects.
\end{abstract}

Keywords Active blended learning · Learner support · Partnership · Student engagement

\section{Introduction}

This article reports on university students' experiences of an institutional pedagogic shift to Active Blended Learning $(\mathrm{ABL})$ at a teaching and employability-focused Higher Education Institution in the United Kingdom. This pedagogic approach was supported by the move to a purpose-built, digitally rich campus without lecture theatres, which consolidated an institutional commitment to teaching in small groups. The study was conducted in 2018 and 2019. It focused on two research questions:

(1) What are students' perceptions of $\mathrm{ABL}$ in relation to their learning, social and support experiences?

Robert Howe

Rob.Howe@northampton.ac.uk

1 University of Portsmouth, University House, Winston Churchill Ave, Portsmouth PO1 2UP, UK

2 Institute of Learning and Teaching, University of Northampton, University Drive, Northampton NN1 5PH, UK

3 Library and Learning Services, University of Northampton, University Drive, Northampton NN1 5PH, UK
(2) What are students' perceived enablers and barriers to successful learning experiences in the context of the institutional shift to ABL?

The analysis of focus groups data resulted in three categories: (1) learning experiences in an ABL setting, (2) social experiences, and (3) learning support. Each category contains several themes. The discussion section reviews these perspectives and identifies enablers and barriers to quality studentcentred learning and teaching within an ABL context.

\section{Active Blended Learning in Context}

The institutional definition states that ABL '[...] combines sense-making activities with focused interactions (with content, peers and tutors) in appropriate learning settings - in and outside the classroom' (University of Northampton 2020). The pedagogical approach is constructivist in nature, with the focus on involving students in building their own knowledge and skills to achieve the learning outcomes. The institution-wide pedagogic shift led to the redesign of all programmes and modules for ABL between 2014 and 2018. Extensive staff development was made available to support the process. 
There are two main dimensions to this pedagogical approach: active and blended. The inclusion of the active learning dimension aims to counter the traditional passive learning experience in HE, reliant on 'broadcast', teacher-centred lecturing (e.g. Schmidt et al. 2010; Schmidt et al. 2015). With active learning elements, students are engaged in collaborative strategies (Zepke and Leach 2010; Palmer et al. 2017; Prince 2004) and in "doing things and thinking about the things they are doing" (Bonwell and Eison 1991, p. 19).

Active learning allows for a consistent student-centred approach to learning and teaching experiences (Andres 2019). Students are encouraged to explore their own knowledge construction, leading to more effective learning (Carlile and Jordan 2005). The use of sense-making tasks and real-life cases (Mikalayeva 2016) has the potential to help develop social skills (Adams Becker et al. 2017), critical thinking (Shin et al. 2014) and problem-solving (Hake 1998). This level of depth and breadth of learning is not achievable through passive approaches (Entwistle 2009; Karagiannopoulou and Entwistle 2013; Karagiannopoulou and Milienos 2015; Marton and Saljo 1976).

Blended learning represents an approach that is becoming common in Higher Education (H.E.) (Adams Becker et al. 2017; Dziuban et al. 2018), although its integration in learning and teaching practices is not always effective. Blended learning must be purposeful and technology should be used to promote learning experiences that would otherwise not be possible (Adams Becker et al. 2017). It can support studentcentredness (Crawford 2017; Matzen and Edmunds 2007), improve student retention and academic achievement (e.g. Boyle et al. 2003; López-Pérez et al. 2011; Potter 2015), and enhance engagement (Dringus and Seagull 2015; Halverson et al. 2014; Kaleta et al. 2007; Reynard 2007). Blended learning can support employability expectations, such as developing digital skills, which are crucial to meeting modern workplace requirements (Ornellas et al. 2019).

Learning and teaching experiences in HE must go beyond developing subject specific knowledge and understanding. Trilling and Fadel (2009), for example, suggest four types of skills for learning in the twenty-first century: 1) core skills such as literacy and numeracy; 2) learning and innovation skills such as critical thinking and creativity; 3 ) career and life skills such as leadership and teamwork; and 4) digital literacy skills. ABL addresses this multidimensional challenge with a strong focus on employability. The active learning elements help develop a sustainable and consistent understanding of core and soft skills, such as critical thinking (Trilling and Fadel 2009). Career and life skills are addressed by both the active and the blended elements through the development of autonomy, accountability, collaboration and cooperation. Digital literacy and fluency are strongly developed through the design of the blended elements of ABL.

Evaluating students' experiences provides valuable data not just to measure the effectiveness of the method, but critically to inform future approaches to pedagogic change. This article reports on this specific institutional experience, but the findings and conclusions may be helpful in informing other large-scale change processes in higher education.

\section{Methodology}

A wide-ranging research project was set up with the aim of evaluating the deployment of ABL across the university. The study comprised three stages. The first two focused on tutors' experiences and are addressed elsewhere (Teixeira Antunes et al. in press). The third stage, which the current article reports on, focused on the student experience.

Six focus groups were conducted, involving a total of 60 students from diverse subject areas. Participation in each focus group was between two and twenty students. These focus groups lasted between 15 and $30 \mathrm{~min}$ and were audio recorded after informed consent was given. No tutors were present during the discussions. The focus groups addressed students' views on the teaching practices of tutors who had taught participants for at least one term and who had themselves taken part in the initial stages of the research. The questions explored examples of effective practice, how pre-session activities link to face-to-face sessions and what students regard as engaging learning experiences.

Thematic analysis was conducted in NVivo by the primary researcher who was contracted by the University for the purposes of this research. The coding and analysis were discussed with the two other researchers, who held permanent positions, to identify and resolve potential inconsistencies and for interrater reliability. Thematic analysis is a suitable approach to analyse qualitative data from diverse participants (Maguire and Delahunt 2017). In the context of a diverse and heterogenous student demographic, including international and mature students, as well as students presenting a range of complex needs, thematic analysis seemed an appropriate choice.

The analysis allowed for the identification of students' perspectives on their learning experiences, its enablers and barriers (Braun and Clarke 2014). Thematic data analysis can be "top-down", where themes are derived in relation to the research questions or particular areas of interest, or "bottomup", where the data fully drives the analysis (Braun and Clarke 2014). A bottom-up approach was adopted to allow data to guide the analysis, rather than limiting the analysis to pre-set themes.

\section{Findings}

The thematic analysis generated three categories and a total of 11 prevalent themes, which were further reviewed to ensure saturation (Table 1). A mapping exercise was conducted to 
Table 1 Themes by category

\begin{tabular}{llll}
\hline Category & Themes & $\begin{array}{l}\text { Number of focus groups } \\
\text { the theme was raised in }\end{array}$ & $\begin{array}{l}\text { Number of times } \\
\text { it was raised }\end{array}$ \\
\hline Learning experiences & Link between theory and practice & 6 & 28 \\
in ABL & Variability in learning experiences & 5 & 15 \\
& Use of technology in learning & 5 & 15 \\
& Engaging learning experiences & 4 & 19 \\
& Pre-session activities & 4 & 15 \\
& Student attendance & 4 & 27 \\
Social experiences & Assessment & 4 & 17 \\
& Communication & 6 & 26 \\
Learning support & Staff-student partnerships & 6 & 23 \\
& Classroom-based support & 5 & 17 \\
& Support beyond the classroom & 6 & 27 \\
\hline
\end{tabular}

ensure consistency between codes and themes and alignment with the research questions, as suggested by Anfara et al. (2002). Representative, coded quotes are used to illustrate each theme. Each code consists of two parts. The first component of the code refers to a student within a focus group (e.g., StA, StB, etc.) and the second specifies which focus group they were part of (e.g., G1, G2, etc.).

\section{Category 1 - Learning Experiences in ABL}

In this category student perspectives focus on 1) approaches to teaching that link theory and practice; 2) diverse, often inconsistent learning experiences; 3) technology in learning and teaching; 4) engaging learning experiences; 5) usefulness of and engagement with pre-session activities; 6) student attendance and 7) assessment.

\section{Link between Theory and Practice}

Most students value learning experiences that clearly link theory and practice as they make them feel better prepared for employment. Being taught by tutors with experience in the relevant professional field further enriches this experience.

I think it provides us with a lot more security coming out of uni because a lot of people come out of uni but don't have experience. [...] if you can apply what you've learnt in theory practically then you're that much easier to getting where you want to be. (StA_G1)

[...] I think it's great that they can bring some of their real-world experience [...]. (StA_G2)

While these experiences are highly valued, there is a sense that learning experiences depend strongly on the individual tutors. Students are aware of the variability in their tutors' practices, as shown in the following theme.

\section{Variability in Learning Experiences}

Students feel they have the right to expect a level of consistency in the quality of their teaching and often take a "value for money" perspective:

[...] we are all paying to be here [...] and I do think there's a massive gap in how teachers will teach, say. (StD G6)

These diverse learning experiences depend on the tutors' personal characteristics, such as passion for their subject and care for their students. Interactions with tutors can illustrate the extent to which students feel supported within and beyond the classroom environment.

But [his] enthusiasm makes it like - he actually like he cares a lot. He cares about what he's teaching you. Like you can see his passion come across. Like with other lecturers it's like they don't even really want to be here. (StD_G3)

Yeah, I feel like she really cares about her students. So if you have a problem, she's really quick at replying to emails. (StB_G6)

One of the areas that illustrates the variability in learning experiences concerns the use of technology in learning, as illustrated in the following theme.

\section{Technology in Learning}

Findings suggest that some tutors use technology in a very limited way in their teaching, while others show strong digital skills and an appetite to integrate technology as a means to enhance their practice. 
I think KuraCloud really helps, especially when I think about other modules, we could also benefit a lot for other, but yeah, I think it really helps [...]. (StD_G1)

Students see attempts to integrate technology as ineffective if they fail to engage or foster interaction. On the other hand, activities can be perceived by students as valuable and effective if they add flexibility and have potential for revision and self-assessment.

But last year there were a lot of videos, weren't there? Like she just put things on the pre-workshop thing [...]. (StC_G5)

The online activities, they give you a set of questions and then, if you don't understand it, there'll be a link to the section where you could read up and try and get an understanding for it. [...] I think that's quite good. (StB_G2)

Many learning technologies depend on a reliable Wi-Fi connection from all campus locations. Access to resources, the ability to take part in synchronous sessions and to contribute to asynchronous tasks all rely on good connectivity. The quality of the wifi was severely affected by the relocation to the new campus in September 2018. Disruption continued for some time after the move.

Like quite a few people had various different problems with the online lectures [...] but then they changed because [tutor name] took feedback from it and tried to work with it as best she could. (StB_G6)

Tutors' ability to respond to student feedback, their resilience to tackle the technological challenges and willingness to adjust practices to increase engagement are also noted by students.

\section{Engaging Learning Experiences}

Students tend to link engaging learning experiences with 'entertainment value'. They associate this value mostly with tutors' personal characteristics rather than the teaching method they use. Some students see engaging teaching as making students feel part of the learning experience and showing openness to students' interventions and suggestions, as also noted in Category 2. Being an active participant in the context of addressing meaningful, interactive tasks, is valued by students as it leads to better understanding of the module content.

He's got a lot of energy. He wakes up everyone. (StB_G3)
Engaging, very engaging, and she makes everyone feel valid and she doesn't ever - no question's ever silly. She's very like open to anything. (StA_G6)

An area where students differ in terms of what engagement means to them, as well as the value of such engagement, is the use of pre-session activities, as discussed next.

\section{Pre-Session Activities}

Pre-session activities were perceived differently by students across the six focus groups. Students link the value of presession tasks mainly with being better prepared to interact in face-to-face sessions. Some students acknowledge that this work is beneficial to their learning experiences but value tutors who cater for students who failed to engage with presession tasks. They feel that when they are unable to complete these pre-session tasks, tutors should ensure they can still benefit from being in the classroom.

But he knows that if you've done the reading, it'll help you, but he understands that not everybody does do it so he like overviews it in class [...]. (StE_G3)

Because I remember last year, they say if you haven't done the reading, don't turn up. But that's going to affect you as well if you don't turn up, kind of thing. (StE_G6)

On the other hand, other students are critical of peers who fail to complete the set pre-session work, which disrupts the learning experience of the whole group. When inconsistent student engagement with tasks is not well managed by tutors, students perceive that the potential benefit is hindered, for example, in terms of the quality of the classroom-based discussion.

And I know that some people didn't have much to say because they didn't actually watch it and, in that case, yeah. No, there wasn't that much to discuss about it. (StC_G5)

\section{Student Attendance}

Students taking part in this research study show concern about the low attendance rates of their peers. They consider that poor-attendance students are disinterested. Low attendance is not attributed to the quality of learning opportunities available. However, students note that face-to-face sessions need to provide added value to motivate attendance.

Because I'm just so surprised why class is always empty. (StC_G1) 
It's not because of the teaching but I guess it's more like people just don't really care. (StC_G1)

Yeah, if I can access all the information now and me coming to class and not learning anything additional, I just kind of feel like [...] It's pointless to come in. (StA G1)

Poor attendance and engagement becomes a serious issue in modules where group work is required, especially for assessment purposes. Students who do engage fear being given lower grades as a result of the lack of engagement by their peers.

Yeah, having to work with people that have made no effort to engage in the module is difficult because you know they will do nothing but bring your grade down. (StA_G1)

Assessment is a major element of the learning experience. Students note how relevant preparation for and performance in summative assessment can be for their development as well as for their future academic success. This aspect is explored in the following theme.

\section{Assessment}

Assessment tasks that provide a clear link between theory and practice and can prepare them for employability are particularly valued by students. These tasks should expand beyond subjectspecific content into values, such as autonomy and integrity.

It's very much like real life. You're kind of thrown a bunch of information and you've got to decide [...] what to do with it. (StA_G2)

$[\ldots]$ they know that a lot of us are going to be going out now into the real world and actually applying what we've learnt in theory, so it's really getting used to being able to do that and very comfortable with doing that. (StA_G1)

The following category expands on the importance of social experiences by focusing on communication and relationshipbuilding between staff and students, leading to the development of partnerships.

\section{Category 2 - Social Experiences}

This section presents findings relating to students' perspectives in relation to two themes: communication and partnerships.

\section{Communication}

Communication in the classroom setting is particularly valued by students. They consistently refer to the benefit associated with tutors' clarity and openness to explain concepts in different ways to ensure understanding. Tutors' attempts to engage students in class discussions, clearly valuing and respecting their perspectives, are highly appreciated by students. Such practices create an environment where students feel like partners in the learning and teaching experience, as explored in the next theme. This communication is most effective when it is not felt as hierarchical, but truly reciprocal. Tutors who are open to feedback and adjust practice accordingly are seen as fostering positive, mutually-beneficial learning environments.

[...] [tutor name] likes to get to know our ideas and our opinions, our perceptions and things. (StB_G6)

He doesn't speak at me. He speaks to me, like I can tell he's engaging. (StA_G1)

$[\ldots]$ she listens to our feedback [...] there's other lecturers that will literally ignore what we've said. (StC_G6)

Students expect effective communication beyond the classroom setting and subject-specific topics. Some tutors are perceived as very approachable in this respect, which positively influences students' satisfaction.

If I were to email him in the evening, even though he's not necessarily at work, he'll reply like within a good time as well. (StA_G1)

[...] like I remember I missed one day, even he said, [...], where are you? so it's like he's always on top to make sure you know what you're doing and he's very like easy to come to if you need help or anything. (StA_G1)

High quality staff-student communication, in and outside the classroom, fosters a closer student connection with tutors and the institution. It plays a central role in the development of partnerships.

\section{Staff-Student Partnerships}

Strong, positive relationships between students and tutors impact on students' willingness to engage with tasks. One of the focus groups highlighted how taking part in this research study was evidence of a positive reciprocal relationship with tutors.

[...] and wanting to stay for like a research thing for her, whereas for other lecturers we probably wouldn't stay like for the half hour that we wouldn't have to. [...] she makes us look good, so why don't we do the same? (StB G6)

The development of positive, constructive partnerships with tutors is seen by students as promoting engagement in the 
learning process. Tutors who are perceived to be stricter, more distant and less approachable make students feel less able to ask for support.

[...] the personality he has makes people want to come to lectures, want to learn, want to do things other than just turning up and not engaging. (StC_G1)

[...] if you're stuck with something you can ask them for help, but as to her you'd feel nervous and think, Oh, she's going to be like, oh, you should have learnt it, kind of thing. (StC_G4)

Students value tutors who treat students as individuals, for example by remembering their names and providing support, even on personal issues.

And he knows me. I'm like, when I see him - and I'm thinking, do you remember my name? (StC_G3)

Yeah, he's very approachable, like if you have any personal issues [...] (StD_G1)

Students recognise the value of learning experiences in small groups as it facilitates the development of closer partnerships with tutors. Some students are clearly aware that these constructive, mutually-beneficial learning experiences are not common in other universities.

It's not like they're - I don't know - this distant person that just comes and gives a presentation and disappears again and you've got to book an appointment with them via email for two weeks' time. (StA_G2)

This sense of availability and ease of access to tutors is one of the factors recognised in the following category, where the focus is learning support.

\section{Category 3 - Learning Support}

\section{Support in the Classroom}

Having time to understand content fully before moving on to further tasks is key for students to develop understanding. Students expect to be able to ask for support and for tutors to provide it in a timely manner. Tutors need to be open to questioning and student feedback.

I kind of like the fact that she puts a lot of focus into specific areas until we've understood it perfectly. (StB G2)

$[\ldots]$ she makes everyone feel valid $[\ldots]$ no question's ever silly. (StA_G6)
While classroom-based support is highly appreciated by students, many focus on the need for this support to extend beyond the classroom. Students expect that support to encompass aspects other than just module content or learning tasks.

\section{Support beyond the Classroom}

The expectation of high quality support beyond the classroom, both in physical and virtual environments, is evident in the data. Students value tutors who are available and approachable, face to face and digitally.

[...] he doesn't only help you in class but he's always willing to help you outside of class. If I want to talk to him after the class, he's still like, "Yeah, I've got 20 minutes; just talk to me," and we'll go through everything. (StC_G1)

He replies to emails quick so if you need any help, he'll be like you have him five minutes there and he'll explain things more. (StD_G1)

The support expected from tutors exceeds academic or module-related requirements. Tutors who promote opportunities for students to acquire professional experience or engage in relevant extracurricular activities are particularly valued. Students recognise the relevance of this work for employability. Opportunities to network within their specific industry areas are also mentioned. Tutors who facilitate these addedvalue experiences are regarded as more motivating and engaging than those who do not.

[...] he sends out a lot of notifications of like courses that are going on or jobs or like internships or volunteering in so many different aspects. (StA_G1) Like she actually got external people to come in to talk to us about what they look for in a CV when they're employing graduates [...] I think that really stood out for me then. (StA_G5)

\section{Discussion}

This article focuses on how university students perceive their learning experiences within the context of an institution-wide pedagogic shift to ABL. Students reflect on their learning experiences independently of labels and without recognition of pedagogic frameworks, as they are largely unaware of the concept of $\mathrm{ABL}$ or the rationale behind this approach. A recently adopted, more accessible narrative around $\mathrm{ABL}$, informed by this study, demonstrates an institutional effort to clarify the concept and engage a wider audience, including current and prospective students: 
Active Blended Learning means our students learn through activities which develop their subject knowledge and confidence in applying professional skills. In Active Blended Learning, students discuss ideas, experiment, work in teams and receive tutor feedback. We value community, collaboration, flexibility, and accessibility, whether on campus or remotely, because we recognise the benefits to our students of digital fluency and flexibility of place and time of study (University of Northampton 2020).

Earlier, staff-focused stages of this study (Teixeira Antunes et al. in press), highlight that student engagement is a core concern for tutors. The literature points to a sector-wide concern with this issue (e.g. Bryson and Hand 2007; Krause and Coates 2008; Masika and Jones 2016; Thomas 2012; Vinson et al. 2010). Other institution-wide studies reviewed approaches to student engagement (e.g. Agyeman 2019; Eboka 2019; Lomer and Palmer under review; Naumov 2019; Read 2019). Factors that promote engagement include positive communication and interactions with peers and tutors (Bryson and Hand 2007; Eboka 2019; Read 2019) and fostering a sense of belonging (Thomas 2012; Masika and Jones 2016).

This study also underlines the relevance of the social dimension to promote student engagement (Armellini and De Stefani 2016). Positive relationships with tutors promote engagement and extend it beyond the immediate learning environment. Students appreciate tutors who take an interest in their personal lives. Effective communication and relationship building enable deeper engagement with academic work and foster a sense of belonging.

Building positive student-tutor partnerships, particularly when students see their tutors as equals, acts as a lever for learner engagement. In their role as partners, students equally contribute to and gain from learning and teaching opportunities and experiences (Bryson 2016; Cook-Sather et al. 2018; Fortune et al. 2018; Matthews et al. 2018). Students link attendance at face-to-face sessions with the value that those sessions add to their learning experience. Students suggest that they are willing to reciprocate by committing to the learning experience in a deeper, more meaningful way.

Participants in this study see their learning experiences as taking place in and outside the classroom, synchronously and asynchronously, individually and in groups. Students value activities for learning and assessment that link theory and practice. Formative activities can be set and reviewed before, during and after face-to-face sessions. Effective and focused interactions with peers, tutors and content (Anderson 2003; McGee and Reis 2012; Monteiro and Morrison 2014) occur based on these tasks in a range of formal and informal settings. The appropriate and purposeful deployment of digital technology enables those interactions and provides flexibility in terms of time, place and pace.
While linking formative tasks to summative assessment is not always highlighted, students strongly acknowledge the importance of their academic work in relation to how it prepares them for employability. Having learning and assessment opportunities that mimic the world of work is seen as essential. Active learning engages students in meaningful tasks that motivate them to make use of a range of skills beyond subjectspecific knowledge (Zepke and Leach 2010; Palmer et al. 2017). The blended element is seen as an enabler of the link between synchronous and asynchronous work, both in and outside the classroom.

One barrier to student engagement and effective learning experiences is referred to by students as the variability in learning experiences across modules and programmes. Students value tutors they see as "going the extra mile". This perception strongly impacts student satisfaction. Students in this study associate these differences with tutors' personal characteristics and circumstances, such as having caring personalities or willingness to demonstrate passion for their subjects (Karagiannopoulou and Entwistle 2019).

Students appear to blur the boundaries between academic and pastoral support. They describe a good learning experience as a personal and holistic one, where the conjunction of subject-specific guidance and help with personal problems is conducive to positive outcomes. Students appreciate tutors who are willing to support them in both areas. While personal tutors often provide solely academic support, pastoral care is increasingly central to their remit (Yale 2019). Further, personal tutoring and other forms of institutional support foster student inclusion and satisfaction (Strayhorn 2012). A sense of belonging is central to student engagement, retention and academic success (Thomas 2012) and plays a key role in promoting wellbeing and positive mental health (McBeath et al. 2018). Both curriculum-related and social activities promote a sense of belonging within the student community (Strayhorn 2012), as do positive relationships with tutors (Yale 2019).

The policies in place at the university where this research was conducted reflect this integrated approach to learner support. The students in this research highlight the importance of guidance beyond the scope of their modules, for example, by being offered opportunities to engage in research or internships. Becoming highly employable graduates with a wide range of transferable skills is a primary concern for students.

The discussion of findings in this section addressed the key themes emerging from the analysis, namely students' perceptions of ABL as they relate to learning, social and support experiences. It also identified enablers and barriers, as seen through the students' lens, to successful learning experiences in an ABL setting. Based on these findings, Fig. 1 summarises the key enablers of a positive learning experience. These dimensions are regarded as core to the overall student experience at the institution where this research was carried out. 
Fig. 1 Enablers for positive learning experiences in an $\mathrm{ABL}$ setting

\section{Conclusions}

This article reports on a study that reviewed university students' perceptions of their learning experiences in the context of a large-scale pedagogic shift to active blended learning. The study addressed two research questions: (1) What are students' perceptions of ABL in relation to their learning, social and support experiences? (2) What are students' perceived enablers and barriers to successful learning experiences?

The findings suggest that a quality learning experience is necessary but not sufficient for a quality overall student experience. The former relates specifically to activities linked to learning and teaching, e.g., participation in seminars and other interactions with tutors and peers for learning and assessment purposes. The overall student experience refers to the broader university context in which that learning occurs. The role of tutors is central to both. To promote student engagement with learning and a sense of belonging, students see the building of partnerships with their tutors as critical. While these findings are institution-specific, they also suggest that universities may benefit from pedagogic approaches that embrace students as partners in learning and teaching.

Students expect productive experiences that permeate different learning settings, of which the classroom is one. They will attend sessions that add value to their learning, while many will skip sessions that do not. Students value, above all, regular synchronous and asynchronous interaction with peers, tutors and content, usually enabled by sound pedagogic design and the appropriate deployment of digital technologies. Students expect activities that promote meaningful interactions before, during and after sessions - whether these are held face to face or online. Employability-focused activities that explicitly link theory and practice are regarded as an integral and essential component of learning and assessment.

Students link their satisfaction primarily with tutors' personality traits. They view support as a holistic, all-encompassing term that integrates academic and pastoral aspects. The boundaries between the different types of support are viewed as artificial and even unhelpful. Learners value tutors who engage in the provision of every form of support that students may require.

\section{Recommendations}

Findings from this research suggest that higher education institutions that engage in pedagogic approaches in line with ABL may need to keep several aspects of their provision and policy under regular review. Recommendations include low cost, high value interventions in terms of curriculum design, teaching practice and learner support:

(a). the role of students as potential partners in co-creation within the ABL curriculum development process.

(b). the integration of employability-focused activities that link theory and practice and provide opportunities for rapid application and transferability. 
(c). the incorporation of focused, student-centred, synchronous and asynchronous interventions at different points, as integral elements of any ABL course.

(d). tutor visibility and engagement throughout.

(e). an integrated and clearly articulated approach to student support, covering academic and pastoral elements of the student experience.

Future research could focus on specific features of staffstudent partnerships in curriculum design within ABL. Research into creative mechanisms to embed meaningful employability-related activity in disciplines often seen as 'purely academic' would also be valuable. A better understanding of the effectiveness of robust, integrated learner support models would strengthen the rationale for and add value to large-scale pedagogic transformation processes.

Open Access This article is licensed under a Creative Commons Attribution 4.0 International License, which permits use, sharing, adaptation, distribution and reproduction in any medium or format, as long as you give appropriate credit to the original author(s) and the source, provide a link to the Creative Commons licence, and indicate if changes were made. The images or other third party material in this article are included in the article's Creative Commons licence, unless indicated otherwise in a credit line to the material. If material is not included in the article's Creative Commons licence and your intended use is not permitted by statutory regulation or exceeds the permitted use, you will need to obtain permission directly from the copyright holder. To view a copy of this licence, visit http://creativecommons.org/licenses/by/4.0/.

\section{References}

Adams Becker, S., Cummins, M., Davis, A., Freeman, A., Hall Giesinger, C., \& Ananthanarayanan, V. (2017). NMC horizon report: 2017 higher Education Edition. Austin, Texas: The New Media Consortium. http://cdn.nmc.org/media/2017-nmc-horizonreport-he-EN.pdf

Agyeman, M. O. (2019). Enhancing student engagement in multidisciplinary groups in Higher Education: A case study of a module taken by Computer Science, Electrical and Electronics Engineering and Mechatronics Engineering students at University of Northampton. In S. Bennett \& M. Nie (2019) Academics as Changemakers: Addressing challenges in HE Teaching Contexts (Issue 1). https:// www.northampton.ac.uk/ilt/academics-as-changemakers/

Anderson, T. (2003). Getting the mix right again: An updated and theoretical rationale for interaction. International Review of Research in Open and Distance Learning, 4, 1(2), -13. https://doi.org/10.19173/ irrodl.v4i2.149.

Andres, H. P. (2019). Active teaching to manage course difficulty and learning motivation. Journal of Further and Higher Education, 43(2), 220-235. https://doi.org/10.1080/0309877X.2017.1357073.

Anfara, V. A., Brown, K. M., \& Mangione, T. L. (2002). Qualitative analysis on stage: Making the research process more public. Educational Researcher, 31(7), 28-38. https://doi.org/10.3102/ 0013189X031007028.
Armellini, A., \& De Stefani, M. (2016). Social presence in the 21st century: An adjustment to the Community of Inquiry Framework. British Journal of Educational Technology, 47(6), 1202-1216. https://doi.org/10.1111/bjet.12302.

Bonwell, C. C. \& Eison, J. A. (1991). Active Learning; Creating Excitement in the Classroom. ASHE-ERIC Higher Education Report No. 1. Washington, D.C.: The George Washington University, School of Education and Human Development. https:// files.eric.ed.gov/fulltext/ED336049.pdf

Boyle, T., Bradley, C., Chalk, P., Jones, R., \& Pickard, P. (2003). Using blended learning to improve student success rates in learning to program. Journal of Educational Media, 28(2-3), 165-178. https://doi.org/10.1080/1358165032000153160.

Braun, V. \& Clarke, V. (2014). What can "thematic analysis" offer health and wellbeing researchers? International Journal of Qualitative Studies in Health and Well-being, 9. https://doi.org/10.3402/qhw. v9.26152.

Bryson, C. (2016). Engagement through partnership: Students as partners in learning and teaching in higher education. International Journal for Academic Development, 21(1), 84-90. https://doi.org/10.1080/ 1360144X.2016.1124966.

Bryson, C., \& Hand, L. (2007). The role of engagement in inspiring teaching and learning. Innovations in Education and Teaching International, 44(4), 349-362. https://doi.org/10.1080/ 14703290701602748.

Carlile, O., \& Jordan, A. (2005). It works in practice but will it work in theory? The theoretical underpinnings of pedagogy. In S. Moore, G. O'Neill, \& B. McMullin (Eds.), Emerging issues in the practice of university learning and teaching. AISHE: Dublin.

Cook-Sather, A., Matthews, K. E., Ntem, A., \& Leathwick, S. (2018). What we talk about when we talk about students as partners. International Journal for students as partners, 2(2), 1-9. https:// doi.org/10.15173/ijsap.v2i2.3790.

Crawford, R. (2017). Rethinking teaching and learning pedagogy for education in the twenty-first century: Blended learning in music education. Music Education Research, 19(2), 195-213. https://doi. org/10.1080/14613808.2016.1202223.

Dringus, L. P., \& Seagull, A. B. (2015). A five-year study of sustaining blended learning initiatives to enhance academic engagement in computer and information sciences campus courses. In A. G. Picciano, C. D. Dziuban, \& C. R. Graham (Eds.), Blended learning: Research perspectives (Vol. 2, pp. 122-140). New York: Routledge.

Dziuban, C., Graham, C., Moskal, P., Norberg, A., \& Sicilia, N. (2018). Blended learning: The new normal and emerging technologies. International Journal of Educational Technology in Higher Education, 15(3). https://doi.org/10.1186/s41239-017-0087-5.

Eboka, T. (2019). Fostering student engagement with diverse cohorts: A case study of BAME undergraduate students. In S. Bennett and M. Nie (2019). Academics as Changemakers: Addressing challenges in HE Teaching Contexts (Issue 1). https://www.northampton.ac.uk/ilt/ academics-as-changemakers/

Entwistle, N. J. (2009). Teaching for understanding at university: Deep approaches and distinctive ways of thinking. Basingstoke: Palgrave Macmillan.

Fortune, T., Borkovic, S., Bhopti, A., Somoza, R., Nhan, H. C., \& Rangwala, S. (2018). Transformative learning through international project-based learning in the global south: Applying a students-aspartners Lens to a "high-impact" capstone. Journal of Studies in International Education, 23(1), 49-65. https://doi.org/10.1177/ 1028315318814571.

Hake, R. R. (1998). Interactive-engagement versus traditional methods: A six-thousand-student survey of mechanics test data for introductory physics courses. American Journal of Physics, 66, 64-74. https:// doi.org/10.1119/1.18809.

Halverson, L. R., Graham, C. R., Spring, K. J., Drysdale, J. S., \& Henrie, C. R. (2014). A thematic analysis of the most highly cited 
scholarship in the first decade of blended learning research. The Internet and Higher Education, 20, 20-34. https://doi.org/10.1016/ j.iheduc.2013.09.004.

Kaleta, R., Skibba, K., \& Joosten, T. (2007). Discovering, designing and delivering hybrid courses. In a. Picciano \& C. Dziuban (Eds.), Blended Learning: Research Perspectives (111-143). Needham, MA: Sloan Center for Online Education (SCOLE).

Karagiannopoulou, E., \& Entwistle, N. J. (2013). Influences on personal understanding: Intentions, approaches to learning, perceptions of assessment, and a 'meeting of minds'. Psychology Teaching Review, 19(2), 80-96. https://doi.org/10.3389/fpsyg.2019.00444.

Karagiannopoulou, E., \& Milienos, F. (2015). Testing two path models to explore relations between experiences of the teaching-learning environment, approaches to learning and academic achievement. Educational Psychology, 35, 26-52. https://doi.org/10.1080/ 01443410.2014 .895800

Karagiannopoulou, E. \& Entwistle, N. (2019). Students' learning characteristics, perceptions of small-Group University teaching, and understanding through a "meeting of minds". Frontiers in Psychology, 22 (vol. 10). https://doi.org/10.3389/fpsyg.2019.00444.

Krause, K.-L., \& Coates, H. (2008). Students' engagement in first-year university. Assessment \& Evaluation in Higher Education, 33(5), 493-505. https://doi.org/10.1080/02602930701698892.

Lomer, S. \& Palmer, E. (under review). 'It is a lazy way of teaching': overcoming student opposition to Active Blended Learning. Submitted $21^{\text {st }}$ August, 2019.

López-Pérez, M. V., Pérez-López, M. C., \& Rodríguez-Ariza, L. (2011). Blended learning in higher education: Students' perceptions and their relation to outcomes. Computers \& Education, 56(3), 818826. https://doi.org/10.1016/j.compedu.2010.10.023.

Maguire, M., \& Delahunt, B. (2017). Doing a thematic analysis: A practical, step-by-step guide for learning and teaching scholars. AISHE$J, 8(3), 3351-33514$

Marton, F., \& Saljo, R. (1976). On qualitative differences in learning II: Outcome as a function of the learner's conception of the task. British Journal of Educational Psychology, 46, 115-127. https://doi.org/10. 1111/j.2044-8279.1976.tb02304.x.

Masika, R., \& Jones, J. (2016). Building student belonging and engagement: Insights into higher education students' experiences of participating and learning together. Teaching in Higher Education, 21(2), 138-150. https://doi.org/10.1080/13562517.2015.1122585.

Matthews, K. E., Dwyer, A., Hine, L., \& Turner, J. (2018). Conceptions of students as partners. Higher Education, 76, 957-971. https://doi. org/10.1007/s10734-018-0257-y.

Matzen, N., \& Edmunds, J. (2007). Technology as a catalyst for change: The role of professional development. Journal of Research on Technology in Education, 39, 417-430. https://doi.org/10.1080/ 15391523.2007.10782490

McBeath, M., Drysdale, M. T. B., \& Bohn, N. (2018). Work-integrated learning and the importance of peer support and sense of belonging. Education + Training, 60(1), 39-53. https://doi.org/10.1108/ET-052017-0070.

McGee, P., \& Reis, A. (2012). Blended course design: A synthesis of best practices. Journal of Asynchronous Learning Networks, 16(4), 7 22. https://doi.org/10.24059/olj.v16i4.239.

Mikalayeva, L. (2016). Motivation, ownership, and the role of the instructor in active learning. International Studies Perspectives, 17(2), 214-229. https://doi.org/10.1093/isp/ekv001.

Monteiro, E., \& Morrison, K. (2014). Challenges for collaborative blended learning in undergraduate students. Educational Research and Evaluation, 20, 564-591. https://doi.org/10.1080/13803611.2014. 997126.
Naumov, N. (2019). 'To do or not to do': Student (non-) engagement with Active Blended Learning. Case Study from Innovation in Tourism \& Hospitality Management and Leading Service Quality in Hospitality. In S. Bennett and M. Nie (2019). Academics as Changemakers: Addressing challenges in HE Teaching Contexts (Issue 1). https://www.northampton.ac.uk/ilt/academics-aschangemakers/

Ornellas, O., Falkner, K., \& Stalbrandt, E. (2019). Enhancing graduates' employability skills through authentic learning approaches. Higher Education, Skills and Work-Based Learning, 9(1), 107-120. https:// doi.org/10.1108/heswbl-04-2018-0049.

Palmer, E., Lomer, S., \& Bashliyska, I. (2017). Overcoming barriers to student engagement with active blended learning. Interim Report. University of Northampton. http://www.northampton.ac.uk/ilt/wpcontent/uploads/sites/2/2017/10/Student-Engagement-with-ABLInterim-Report-v3-October-2017.pdf

Potter, J. (2015). Applying a hybrid model: Can it enhance student learning outcomes? Journal of Instructional Pedagogies, 17, 1-11.

Prince, M. (2004). Does active learning work? A review of the research. Journal of Engineering Education, 93(3), 223-231. https://doi.org/ 10.1002/j.2168-9830.2004.tb00809.x.

Read, S. (2019). Fostering engagement in assessed group work with diverse cohorts. Case study from Introduction to Marketing Communications (MKT1002). In S. Bennett \& M. Nie (2019). Academics as Changemakers: Addressing challenges in $H E$ Teaching Contexts (Issue 1). https://www.northampton.ac.uk/ilt/ academics-as-changemakers/

Reynard, R. (2007). Hybrid Learning: Maximizing Student Engagement. https://campustechnology.com/articles/2007/05/hybrid-learningmaximizing-student-engagement.aspx

Schmidt, H. G., Cohen-Schotanus, J., Van der Molen, H. T., Splinter, T. A. W., Bulte, J., Holdrinet, R., \& van Rossum, H. J. M. (2010). Learning more by being taught less: A 'time-for-self-study' theory explaining curricular effects on graduation rate and study duration. Higher Education, 60(3), 287-300. https://doi.org/10.1007/s10734009-9300-3.

Schmidt, H. G., Wagener, S. L., Smeets, G. A. C. M., Keemink, L. M., \& van der Molen, H. T. (2015). On the use and misuse of lectures in higher education. Health Professions Education, 1(1), 12-18. https://doi.org/10.1016/j.hpe.2015.11.010.

Shin, H., Sok, S., Hyun, K. S., \& Kim, M. J. (2014). Competency and an active learning program in undergraduate nursing education. Journal of Advanced Nursing (JAN), 71(3), 591-598. https://doi. org/10.1111/jan.12564.

Strayhorn, T. L. (2012). College students' sense of belonging: A key to educational success for all students. New York: Routledge.

Teixeira Antunes, V., Armellini, A. \& Howe, R. (in press). Beliefs and engagement in an institution-wide pedagogic shift. Teaching in Higher Education.

Thomas, L. (2012). Building student engagement and belonging in higher education at a time of change: Final report from the what works? Student retention and success programme. London: Paul Hamlyn Foundation, Higher Education Funding Council for England, The Higher Education Academy and Action on Access. https://www. heacademy.ac.uk/sites/default/files/resources/What_works_final_ report.pdf

Trilling, B. \& Fadel, C. (2009). 21st century skills: Learning for life in our times. Jossey-Bass/Wiley.

University of Northampton - Institute of Learning and Teaching in Higher Education (2020). Defining Active Blended Learning. http://www. northampton.ac.uk/ilt/current-projects/defining-abl/. 
Vinson, D., Nixon, S., Walsh, B., Walker, C., Mitchell, E., \& Zaitseva, E. (2010). Investigating the relationship between student engagement and transition. Active Learning in Higher Education, 11, 131-143. https://doi.org/10.1177/1469787410365658.

Yale, A. T. (2019). The personal tutor-student relationship: Student expectations and experiences of personal tutoring in higher education. Journal of Further and Higher Education, 43(4), 533-544. https:// doi.org/10.1080/0309877X.2017.1377164.
Zepke, N., \& Leach, L. (2010). Improving student engagement: Ten proposals for action. Active Learning in Higher Education, 11(3), 167-177. https://doi.org/10.1177/1469787410379680.

Publisher's Note Springer Nature remains neutral with regard to jurisdictional claims in published maps and institutional affiliations. 